\title{
Assessment of Genetic Diversity Among Groundnut (Arachis Hypogaea L.) Genotypes
}

\author{
Namrata $^{{ }^{*}}$, Hemlata Sharma ${ }^{1}$, Prashant Bisen ${ }^{1}$, Bhumica Singh ${ }^{2}$ and Surbhi Jain ${ }^{1}$ \\ ${ }^{1}$ Dept. of Plant Breeding and Genetics, ${ }^{2}$ Dept. of Molecular Biology and Biotechnology, Maharana Pratap University of Agriculture \\ and Technology, Udaipur, Rajasthan (313 001), India
}

\section{Corresponding Author}

Namrata

e-mail: namratamotasara@gmail.com

\author{
Article History \\ Article ID: 3 C0848 \\ Received in 02 ${ }^{\text {nd }}$ November, 2017 \\ Received in revised form 29th $A$ pril, 2018 \\ Accepted in final form $24^{\text {th }}$ May, 2018
}

\begin{abstract}
In present experiment the genetic diversity studied among 30 genotypes of groundnut using $D^{2}$ statistic during kharif - 2014 in a randomized block design with three replications at the Instructional Farm, College of Technology and Engineering, Maharana Pratap University of Agriculture and Technology, Udaipur for thirteen agro-morphological characters including days to $50 \%$ flowering, days to maturity, plant height $(\mathrm{cm})$, number of branches plant ${ }^{-1}$, number of mature pods per plant, dry pod yield plant ${ }^{-1}(\mathrm{~g})$, kernel yield per plant $(\mathrm{g}), 100-k e r n e l$ weight $(\mathrm{g})$, sound mature kernels (\%), shelling percentage, biological yield per plant, harvest index (\%) and oil content (\%). The analysis of variance revealed significant differences among the genotypes for all characters except days to $50 \%$ flowering and days to maturity. Based on Ward's method, 30 genotypes were grouped into two clusters. Cluster I was containing 29 genotypes while cluster II contained only 1 genotype i.e. UG-179. Inter cluster distance between these two clusters was observed 159.68, which proved UG-179 genotype sufficiently different from the rest 29 genotypes. Cluster means revealed that genotypes from these two clusters may be used for future hybrid groundnut breeding programs with special reference to dry pod yield, 100-kernel weight, biological yield, harvest index and oil content. The diversity present among the genotypes helps in producing better high oil groundnut genotypes for the developing countries while low oil genotypes having high confectionary quality also produced as per the demand of groundnut in the developed countries for food purposes.
\end{abstract}

Keywords: Groundnut, D2 statistics, genetic diversity, inter cluster

\section{Introduction}

Groundnut (Arachis hypogaea L.) is the sixth most important oilseed crop in the world and grown for its high amount of oil (45-50\%) and digestable protein (25-30\%) throughout the world (Namrata et al., 2016; Dhakar et al., 2017). Groundnut is also known as "King of Oilseed" because it contains poly unsaturated fatty acids (PUFA) $(40-50 \%)$ and mono unsaturated fatty acids (MUFA) like linoleic acid (25$35 \%$ ) in right proportion which makes groundnut oil stable and nutritive (Rani, 2017; Gantait et al., 2017; Wang, 2018). Rancidity development in the oil is prevented by the presence of an antioxidant (tocopherol content approximately 0.9 $\mathrm{mg} / \mathrm{g}$ oil) (Kushwah et al., 2016). Groundnut is also used for food purposes like groundnut butter, roasted groundnut and salted groundnut etc. in western part of the world (Nigam et al., 2004; Janila, 2016). So, in groundnut breeding cultivars with high oil for oil production and also cultivars with low oil for confectionary purposes are very important. Common problem faced by breeders in groundnut breeding is that most groundnut cultivars have a narrow genetic base that is due to recent polyploidization, self-pollination and lack of sufficient informations about morphological and agricultural characteristics of groundnut (Badigannavar et al., 2002; Nigam et al., 2004). Precise information about the nature and degree of genetic diversity present in a population is must for the plant breeder because it helps in selection of most diverse parents which results in a hybrid with high heterosis (Kumari et al., 2015; Reddy, 2017). Knowledge of pre- existing genetic diversity is the basic need of any crop improvement programme (Bhakal, 2015). Hence, the present investigation was made to study the genetic divergence in 30 genotypes of groundnut (Arachis hypogaea L.) to identify potential genotypes for various yield traits which could be utilized in the hybridization programme as parents.

\section{Materials and Methods}

\subsection{Experimental site and design}

The experimental material composed of 30 groundnut genotypes including three checks namely Pratap Raj Mungphali, Pratap Mungphali-2, TG-37A (Table 1), were planted in a Randomized Block Design with three replications during kharif, 2014 at the Instructional Farm, College of 


\begin{tabular}{|c|c|c|}
\hline SI. No. & Name of genotypes & Pedigree \\
\hline 1. & UG-158 & J $63 \times T P G ~ 41$ \\
\hline 2. & UG-159 & JSSP 15×JSSP 24 \\
\hline 3. & UG-160 & GG 2×B 95 \\
\hline 4. & UG-161 & GG 8×TKG $19 \mathrm{~A}$ \\
\hline 5. & UG-162 & GG 2×TPG 41 \\
\hline 6. & UG-163 & GG 20×PBS 24030 \\
\hline 7. & UG-164 & ICGX 090018 \\
\hline 8. & UG-165 & GG 21×R-2001-3 \\
\hline 9. & UG-166 & GG 8×TKG 19 A \\
\hline 10. & UG-167 & GG $2 \times T G 26$ \\
\hline 11. & UG-168 & GG 20×TAG 24 \\
\hline 12. & UG-169 & GG 20×ICGV 86325 \\
\hline 13. & UG-170 & GG-7×R-2001-3 \\
\hline 14. & UG-171 & GG-7×JL 501 \\
\hline 15. & UG-172 & TG-37 A×GG 20 \\
\hline 16. & UG-173 & GG 2×ICGV 91114-1 \\
\hline 17. & UG-174 & TG 40×ICGV 86325 \\
\hline 18. & UG-175 & PBS 24030×TG 37 A \\
\hline 19. & UG-176 & ICGX 070067 \\
\hline 20. & UG-177 & J 11×TPG 41 \\
\hline 21. & UG-178 & ICGV 76×ICGV 86305 \\
\hline 22. & UG-179 & ICGV 86564×TPG 41 \\
\hline 23. & UG-180 & TG $37 \mathrm{~A} \times \mathrm{CS} 19$ \\
\hline 24. & UG-181 & ICGV 86590×PBS 24030 \\
\hline 25. & UG-182 & UG $20 \times A L R-3$ \\
\hline 26. & UG-183 & GG 5×Faizapur-2 \\
\hline 27. & UG-184 & GG 5×TPG 41 \\
\hline 28. & Pratap Mungphali -2 & ICGV- $86055 \times$ ICG- (FDRS 10) \\
\hline 29. & Pratap Raj Mungphali & Selection from ICGV 98223 \\
\hline 30. & TG-37A & TG $25 \times$ TG 26 \\
\hline
\end{tabular}

Technology and Engineering, Maharana Pratap University of Agriculture and Technology, Udaipur. In each replication, genotypes were sown in a plot of $5 \times 0.9 \mathrm{~m}^{2}$ accommodating 3 rows of $5 \mathrm{~m}$ length, spaced $30 \mathrm{~cm}$ apart with a plant to plant spacing of $10 \mathrm{~cm}$. Recommended agronomic practices were followed to raise a healthy crop.

\subsection{Recording of data}

The data were recorded on five randomly selected competitive plants of each genotype for thirteen agro-morphological characters, except days to $50 \%$ flowering, days to maturity and 100-kernel weight, which were recorded on plot basis.

\subsection{Biochemical analysis}

Two random samples of kernels were drawn from bulk harvest of five randomly selected plants under each replication and oil content of kernels was determined by the Soxhlet's Method (A.O.A.C., 1965) and average oil content in per cent was worked out.

\subsection{Statistical analysis}

The mean value of the recorded data was subjected to analysis of variance (ANOVA) using the statistical method suggested by Fisher (1918). Multivariate analysis of $D^{2}$ was done for all thirteen characters by using Mahalanobis Statistics (1936) and clusters were formed by following the Ward (1963) method.

\section{Results and Discussion}

The significant treatment mean square indicated adequate variability among the genotype for almost all characters, except days to 50 per cent flowering and days to maturity (Table 2) which indicated the presence of considerable

\begin{tabular}{|c|c|c|c|c|}
\hline \multirow[t]{2}{*}{$\begin{array}{l}\text { Sl. } \\
\text { No. }\end{array}$} & Characters & $\begin{array}{l}\text { Replica- } \\
\text { tion }\end{array}$ & Genotype & Error \\
\hline & d.f. & [2] & [29] & [58] \\
\hline 1. & $\begin{array}{l}\text { Days to } 50 \% \text { flower- } \\
\text { ing }\end{array}$ & 10.5333 & 4.1471 & 4.453 \\
\hline 2. & Days to maturity & 3.2444 & 5.3870 & 3.336 \\
\hline 3. & Plant height $(\mathrm{cm})$ & 5.2724 & $10.9413^{* *}$ & 2.444 \\
\hline 4. & $\begin{array}{l}\text { No. of branches } \\
\text { plant }^{-1}\end{array}$ & 0.2111 & $1.4410^{*}$ & 0.7513 \\
\hline 5. & $\begin{array}{l}\text { No. of mature pods } \\
\text { plant }^{-1}\end{array}$ & 3.2333 & $13.2034^{* *}$ & 2.44 \\
\hline 6. & $\begin{array}{l}\text { Dry pod yield plant }{ }^{-1} \\
\text { (g) }\end{array}$ & 0.2111 & $16.7697^{* *}$ & 1.659 \\
\hline 7. & $\begin{array}{l}\text { Kernel yield plant }{ }^{-1} \\
\text { (g) }\end{array}$ & 0.4767 & $7.7246^{* *}$ & 1.194 \\
\hline 8. & $\begin{array}{l}\text { 100-Kernel weight } \\
\text { (g) }\end{array}$ & 1.4333 & $110.6299^{* *}$ & 0.9391 \\
\hline 9. & $\begin{array}{l}\text { Sound mature ker- } \\
\text { nels (\%) }\end{array}$ & 1.9111 & $27.1249^{* *}$ & 2.256 \\
\hline 10. & Shelling percentage & 6.6778 & $29.3444^{* *}$ & 8.069 \\
\hline 11. & $\begin{array}{l}\text { Biological yield } \\
\text { plant }^{-1}\end{array}$ & 33.6333 & $62.3126^{* *}$ & 26.21 \\
\hline 12. & Harvest index (\%) & 17.1700 & $65.2100^{* *}$ & 22.13 \\
\hline 13. & Oil content (\%) & 1.2444 & $18.9962^{* *}$ & 0.5433 \\
\hline
\end{tabular}

[] Figures in parenthesis are degrees of freedom; $*, * *$ : Significant at $(p=0.05)$ and $(p=0.01)$ level of significance, respectively 
variability among the genotypes under study. On the basis of observed magnitude of the $D^{2}$ value, 30 groundnut genotypes were grouped into two clusters, in such a manner that the genotypes within the cluster had smaller $D^{2}$ value than the genotype from different cluster. Cluster I contain almost all genotypes i.e. 29, included in the experiment while cluster II contains only single genotype i.e. UG-179 (Table 3). Clustering pattern revealed that genotypes from quite different pedigree fall into a single cluster I which could be explained by the presence of unidirectional selection pressure for development of the genotypes which made them genetically similar as compared to their parents. The genotypes from the same origin may be present in same cluster or not, like UG-162 and UG-167 having one parent common (GG 2) are found in same cluster I while on other hand genotype UG-179 and UG-184 also having one parent common (TPG 41) but found in different clusters, cluster II and cluster I, respectively (Table 1) (Table 3). Looking at the pattern of varietal distribution in different clusters, it appeared that geographical distance between the varieties had no relation with the genetic divergence as the varieties

\begin{tabular}{lll}
\hline \multicolumn{2}{l}{ Table 3: Groundnut genotypes included in each cluster } \\
\hline Clusters & $\begin{array}{l}\text { No. of geno- } \\
\text { types }\end{array}$ & Name of genotypes \\
\hline I & 29 & UG-158, UG-159, UG-160, UG-161, \\
& UG-162, UG-163, UG-164, UG-165, \\
& UG-166, UG-167, UG-168, UG-169, \\
& UG-170, UG-171, UG-172, UG-173, \\
& UG-174, UG-175, UG-176, UG-177, \\
& UG-178, UG-180, UG-181, UG-182, \\
& & UG-183, UG-184, Pratap Mungpha- \\
& Ii-2, Pratap Raj Mungphali, TG-37A \\
\hline
\end{tabular}

from same source had fallen into different clusters as well as the same cluster contained varieties from different sources. The similar results were found by Islam et al. (2005). On considering mean of characters with respect to these two clusters, significant difference was observed for most of the traits under study (Table 4). Genotypes belonging to cluster II having higher mean values for number of mature pods plant $^{-1}(6.67)$, dry pod yield plant ${ }^{-1}(15.67 \mathrm{~g})$, kernel yield plant $^{-1}(10.66 \mathrm{~g}), 100$ kernel weight $(60.00 \mathrm{~g})$, sound mature kernel $(90.33 \%)$, biological yield plant ${ }^{-1}(42.00 \mathrm{~g})$, harvest index (37.47) and oil content (41.67\%). This revealed that the genotypes from these two clusters able to produce desirable transgressive segregates for above mentioned characters upon hybridization and can provide an opportunity for selection of better genotypes in succeeding generations of groundnut breeding programmes. This enables breeder to produce genotypes with high oil content for developing countries and low oil genotypes used in confectionary
Table 4: Cluster mean values of 13 different characters of 30 genotypes

\begin{tabular}{lcc}
\hline Character/ Cluster & Cluster I & Cluster II \\
\hline DF & 28.57 & 29.33 \\
DM & 100.40 & 105 \\
PH & 29.53 & 29.20 \\
NBP & 5.09 & 8 \\
NMP & 11.18 & 6.67 \\
DPY & 11.89 & 15.67 \\
KYP & 8.36 & 10.66 \\
KW & 42.83 & 60 \\
SMK & 88.63 & 90.33 \\
SP & 70.43 & 68 \\
BYP & 36 & 42.00 \\
HI & 33.35 & 37.47 \\
OC & 37.76 & 41.67 \\
\hline
\end{tabular}

DF: Days to $50 \%$ flowering; DM: Days to maturity; PH: Plant height; NBP: No. of branches plant ${ }^{-1}$; NMP: No. of mature pods plant ${ }^{-1}$; DPY: Dry pod yield plant $^{-1}$; KYP: Kernel yield plant $^{-1}$; KW: 100-Kernel weight; SMK: Sound mature kernel; SP: Shelling percentage; BY: Biological yield plant ${ }^{-1}$; HI: Harvest index; OC: Oil Content

purposes for developed countries.

Although adequate amount of variability present among the genotypes but it was not evenly distributed so we obtained only two clusters. Average intra cluster distance observed within cluster I was 51.35 while in cluster II it was 0 because it contains only single genotype UG-179, these finding are in contrast with Verma et al. (2006), Peshattiwar et al. (2009). While considering inter cluster distances, cluster I and cluster II exhibited very high inter- cluster distance (159.68), these finding are in close agreement with Dolma et al. (2010), Zaman et al. (2010), Yadav et al. (2014) and Dhakar et al. (2017). This revealed that only one genotype under study, UG 179 significantly different from others so it is strongly advised to use this genotype in hybridization with the members of cluster I for groundnut improvement programs (Table 5).

Table 5: Average intra and inter-cluster $D^{2}$ values in 30 genotypes of groundnut

\begin{tabular}{lcc}
\hline Cluster & I & II \\
\hline I & 51.35 & 159.68 \\
II & 159.68 & 0.00 \\
\hline
\end{tabular}

\section{Conclusion}

Genotypes from cluster I and II could be used for the production of the desirable transgressive segregants with 
special reference to characters like dry pod yield, 100-kernel weight, biological yield, harvest index and oil content which helps in producing better groundnut genotypes with high oil according to the demand of developing countries for oil production or low oil genotypes having high confectionary quality according to the demand in the developed countries for food purposes which ensures better future of groundnut improvement programs.

\section{References}

A.O.A.C., 1965. Official methods for oil analysis for association of Official Agricultural Chemists. 10 ${ }^{\text {th }}$ (Edn.). Washington, D.C.

Bhakal, M., Lal, G.M., 2015. Studies on Genetic Diversity in Groundnut (Arachis hypogaea L.) Germplasm. Journal of Plant Science Research 2(2), 128.

Dhakar, T.R., Sharma, H., Namrata, Bisen, P., 2017. Genetic diversity analysis in groundnut (Arachis hypogaea L.) genotypes using $D^{2}$ statistics. Indian Journal of Ecology 44(4), 175-181.

Dolma, T., Sekhar, M.R., Reddy, K.R., 2010. Genetic variability and character association in Spanish bunch groundnut (Arachis hypogaea L.). Journal of Oilseeds Research 27, 158-160.

Fisher, R.A., 1918. The correlations among relatives on the supposition of Mendelian inheritance. Transactions Royal Society, Edinburg, 52, 399-433.

Gantait, S., Gunri, S.K., Kundu, R., Chatterjee, S., 2017. Evaluation of Genetic Divergence in Spanish Bunch Groundnut (Arachis hypogaea Linn.) Genotypes. Plant Breeding and Biotechnology 5(3), 163-171.

Islam, M.T., Alam, S., Islam, M.Z., Hossain. M.K., 2005. Genetic variability and diversity of groundnut (Arachis hypogaea L.) The Agriculturist 3(1\&2), 96-103.

Janila, P., Variath, M.T., Pandey, M.K., Desmae, H., Motag, $i$ B.N., Okori, P., Manohar, S.S., Rathnakuma,r A.L., Radhakrishnan, T., Liao, B., Varshney, R.K., 2016. Genomic Tools in Groundnut Breeding Program: Status and Perspectives. Frontiers in Plant Science 7, 289.

Kumari, S., Singh, S.K., 2015. Assessment of genetic diversity in promising finger millet (Eleusine coracana L.) genotypes. The Bioscan 10(2), 825-830.

Kushwah, A., Gupta, S., Sharma, S.R., Pradhan, K., Kaur, K., 2016. Study on genetic diversity in groundnut (Arachis hypogaea L.) using morphological markers. The Bioscan
11(4), 3105-3109.

Mahalonobis, P.C., 1936. A statistical study at chinese head measurement. Journal of Asiatic Society of Bengal 25, 301-377.

Namrata, Sharma, H., Ranwah, B.R., Bisen, P., 2016. Variability assessment and path coefficient analysis in groundnut (Arachis hypogaea L.) genotypes in sub- humid southern plains of rajasthan. Trends in Biosciences 9(11), 642-646.

Nigam, S.N., Giri, D.Y., Reddy, A.G.S., 2004. Groundnut seed production manual. Patancheru 502324, Andhra Pradesh, India: International Crops Research Institute for the Semi-Arid Tropics. 32.

Peshattiwar, P.D., Ghorpade, P.B., Dandge, M.S., Thorat, A., Gomase, D.G., 2009. Genetic divergence in duram wheat cultivars. International journal of Agricultural Sciences 5, 243-247.

Rani, A.R., 2017. Stem rot of groundnut incited by sclerotium Rolfsii sacc. And it's management - a review. International Journal of Agricultural Science and Research 7(3), 327-338.

Reddy, A.L., Reddy, C.M.M., Srinivas, T., 2017. Assessment of multivariate analysis for kernel yield and yield component traits in drought tolerant groundnut genotypes. Plant Archives 17(2), 985-987.

Verma, A.K., Singh, P.K., Vishwakarma, S.R., Tripathi, R.M., 2006. Genetic divergence in wheat (T. aestivum L.). Farm Science Journal 15, 32-34.

Wang, Q., 2018. Relationship between raw material quality and product quality of peanut. In: peanut processing characteristics and quality evaluation. Springer, Singapore, https://doi.org/10.1007/978-981-10-61752_4.

Ward, J.H., 1963. Hierarchical grouping to optimize an objective function. Journal of American statistical Association 58, 236-244.

Yadav, S.R., Rathod, A.H., Shinde, A.S., Patade, S.S., Patil, C.N., Vaghela, P.O., 2014. Genetic variability and divergence studies in groundnut (Arachis hypogea L.) International. Journal of agric Sciences 10, 691-694.

Zaman, M.A., Khatun M.T., Ullah, M.Z., Moniruzzamn, M., Alam, K.H., 2011. Genetic variability and path analysis of groundnut (Arachis hypogaea L.). The Agriculturists 9, 29-36. 